\begin{tabular}{|l|l|l|}
\hline \multicolumn{2}{|c|}{ PublisherInfo } \\
\hline \hline PublisherName & $:$ & BioMed Central \\
\hline \hline PublisherLocation & $:$ & London \\
\hline \hline PublisherImprintName & $:$ & BioMed Central \\
\hline \hline
\end{tabular}

\title{
RAF, RAS and mismatch repair
}

\begin{tabular}{|l|l|l||}
\hline \multicolumn{2}{|c|}{ ArticleInfo } \\
\hline \hline ArticleID & $:$ & 4566 \\
\hline \hline ArticleDOI & $:$ & $10.1186 /$ gb-spotlight-20020830-01 \\
\hline \hline ArticleCitationID & $:$ & spotlight-20020830-01 \\
\hline \hline ArticleSequenceNumber & $:$ & 232 \\
\hline \hline ArticleCategory & $:$ & Research news \\
\hline ArticleFirstPage & $:$ & 1 \\
\hline \hline ArticleLastPage & $:$ & 2 \\
\hline \hline & & RegistrationDate : 2002-8-30 \\
\hline ArticleHistory & $:$ & OnlineDate \\
\hline \hline ArticleCopyright & $:$ & BioMed Central Ltd2002-8-30 \\
\hline \hline ArticleGrants & $:$ & \\
\hline \hline ArticleContext & $:$ & 130593311 \\
\hline \hline
\end{tabular}




\section{Jonathan B Weitzman}

Email: jonathanweitzman@hotmail.com

Researchers recently reported mutations in the BRAF gene in melanomas. In a Brief Communication in the August 29 Nature, Rajagopalan et al. report their analysis of $R A F$ and $R A S$ mutations in 330 colorectal tumour samples (Nature 2002, 418:934). They found 32 mutations in BRAF and 169 mutations in KRAS (often in larger adenomas), but never both at the same time. They also found that colorectal tumors unable to repair DNA mismatches had a high incidence of $B R A F$ mutations and a lower incidence of $K R A S$ mutations, highlighting that the mutation spectrum depends on the nature of the tumor genetic instability. Thus $B R A F$ and $K R A S$ mutations appear to be equivalent in their tumorigenic effect, both playing a role after initiation and before malignant conversion.

\section{References}

1. Melanoma susceptibility gene, [http://www.the-scientist.com/news/20020611/03]

2. Nature, [http://www.nature.com] 